\title{
Effect of Vermisilt and Inorganic Fertilizers on Urease and Dehydrogenase Enzyme Activities Insoil at Different Crop Growth Stages of Maize
}

\author{
B. Naveenkumar*, G. Padmaja, T. Ram Prakash, M. Madhavi and S. Narender Reddy
}

Department of Soil Science and Agricultural Chemistry, College of Agriculture, Professor Jayashankar Telangana State Agricultural University, Hyderabad-30, India

*Corresponding author

\section{Keywords}

Maize (Zea mays L.), Rajendranagar, Hyderabad

Article Info

Accepted:

12 July 2019

Available Online:

10 August 2019

\section{A B S T R A C T}

The field experiment was conducted with maize during kharif on a sandy loam soil at College Farm, College of Agriculture, Rajendranagar, Hyderabad. The experiment was laid out in Randomized Block Design with 13 treatments, each replicated thrice. The urease and dehydrogenase activites in soil were assayed and the results showed an increasing trend in enzymatic activities with the age of the crop and exhibited highest activity at tasseling stage and thereafter the activity decreased towards maturity and harvest. Urease activity at vegetative, tasseling and at harvesting stage of maize was significantly higher, the activities being 43.27, 55.30 and 34.15 $\mu \mathrm{g}$ of $\mathrm{NH}_{4}^{+}-\mathrm{N}$ released $\mathrm{g}^{-1}$ soil $2 \mathrm{~h}^{-1}$, respectively followed by $\mathrm{T}_{13}(75 \%$ $\left.\mathrm{RDF}+\mathrm{SV}_{4} @ 6 \mathrm{t} \mathrm{ha}^{-1}\right)$. Similar results were also recorded of dehydrogenase activity at vegetative, tasseling and at harvesting stage of maize.

\section{Introduction}

Maize (Zea mays L.) is an important crop among cereals which occupies third rank after wheat and rice in the world. In India, maize is cultivated in an area of about 9.38 million hectares with a production and productivity of 28.75 million tonnes and 3.06 tonnes per hectare, respectively (Indiastat, 2017-18) and the area under maize cultivation has been increasing significantly. Maize is known for its wider adaptability and multipurpose uses as food, feed, fodder and raw material for industries. Use of chemical fertilizers alone may not keep pace with time in maintenance of soil health for sustaining the productivity. The escalating costs of fertilizers and undesirable effects on soil properties have led to the inclusion of organic manures in cultivation of crops. In recent years several experimental results revealed that neither the fertilizers nor the organic sources in isolation can achieve sustained productivity under intensive cropping systems. In this context, there is need to adopt a rationalistic INM approach to have an 'Evergreen Revolution'. 
So far the studies were concentrated on tank silt and vermicompost alone. However the mixture of vermicompost and tank silt (vermisilt) will have a promising role in improving the physical, chemical and biological properties of a soil, conducive for enhanced crop production. Keeping in view the gaps, the study wasplanned to investigate the effect of vermisilt and inorganic fertilizers on soil enzymes activities.

\section{Materials and Methods}

A field experiment was conducted on sandy loam soil at college farm, college of agriculture, Rajendranagar, Hyderabad during kharif -2015. Soil of the experimental field is a sandy loam, moderately alkaline (7.7), nonsaline (EC- $0.28 \mathrm{dS} \mathrm{m} \mathrm{m}^{-1}$ ), low in organic carbon $(0.48 \%)$, available nitrogen $(238.8 \mathrm{~kg}$ $\left.\mathrm{ha}^{-1}\right)$ and available potassium $(263.9 \mathrm{~kg} \mathrm{~K} 2 \mathrm{O}$ $\left.\mathrm{ha}^{-1}\right)$ and high in phosphorus $\left(32.10 \mathrm{~kg} \mathrm{P}_{2} \mathrm{O}_{5}\right.$ $\left.\mathrm{ha}^{-1}\right)$. Vermi compost and tank silt were used in the experiment. Vermi compost was collected from Agri Biotech Foundation, Agricultural University Campus, Rajendranagar, Hyderabad.

Tank silt was obtained from Hyderabad Metropolitan Development Authority. The different combinations of vermisilt were prepared by mixing the tank silt and vermicompost in proper combinations as per the ratios $\left[\mathrm{SV}_{1}(10: 2), \mathrm{SV}_{2}(10: 3), \mathrm{SV}_{3}(10: 4)\right.$ and $\left.\mathrm{SV}_{4}(10: 5)\right]$.

An experiment was laid out in randomized block design with 13 treatments and replicated thrice. The treatments include $\mathrm{T}_{1}$ (absolute control), $\mathrm{T}_{2}$ Only RDF (200: 60: $50 \mathrm{~N}: \mathrm{P}_{2} \mathrm{O}_{5}$ : $\left.\mathrm{K}_{2} \mathrm{O} \quad \mathrm{kg} \quad \mathrm{ha}^{-1}\right), \quad \mathrm{T}_{3} \quad\left(\mathrm{SV}_{4} \quad(10: 5 \quad\right.$ vermisilt

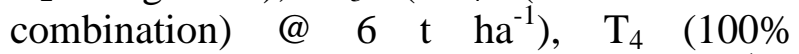
Recommended dose of fertilizers $+6 \mathrm{t} \mathrm{ha}^{-1}$ of $\left.\mathrm{SV}_{2}\right), \quad \mathrm{T}_{5}(100 \%$ Recommended dose of fertilizers $+4 \mathrm{t} \mathrm{ha}{ }^{-1}$ of $\left.\mathrm{SV}_{3}\right), \mathrm{T}_{6}(100 \%$ Recommended dose of fertilizers $+6 \mathrm{t} \mathrm{ha}^{-1}$ of
$\left.\mathrm{SV}_{3}\right), \quad \mathrm{T}_{7} \quad(100 \%$ Recommended dose of fertilizers $+4 \mathrm{t} \mathrm{ha}^{-1}$ of $\left.\mathrm{SV}_{4}\right), \mathrm{T}_{8} \quad(100 \%$ Recommended dose of fertilizers $+6 \mathrm{tha}^{-1}$ of $\left.\mathrm{SV}_{4}\right), \quad \mathrm{T}_{9} \quad(75 \%$ Recommended dose of fertilizers $+6 \mathrm{t}$ ha ${ }^{-1}$ of $\left.\mathrm{SV}_{2}\right), \mathrm{T}_{10}(75 \%$ Recommended dose of fertilizers $+4 \mathrm{tha}^{-1}$ of $\left.\mathrm{SV}_{3}\right), \mathrm{T}_{11}(75 \%$ Recommended dose of fertilizers $+6 \mathrm{t} \mathrm{ha}^{-1}$ of $\left.\mathrm{SV}_{3}\right), \mathrm{T}_{12}(75 \%$ Recommended dose of fertilizers $+4 \mathrm{tha}^{-1}$ of $\left.\mathrm{SV}_{4}\right)$ and $\mathrm{T}_{13}(75 \%$ Recommended dose of fertilizers $+6 \mathrm{tha}^{-1}$ of $\left.\mathrm{SV}_{4}\right)$.

Soil Urease activity was assayed by quantifying the rate of release of $\mathrm{NH}_{4}{ }^{+}$from the hydrolysis of urea as described by Tabatabai and Bremner (1972). Dehydrogenase activity was assayed by quantifying the 2,3,5-triphenyl formazan (TPF) produced and expressed as $\mathrm{mg}$ TPF produced $\mathrm{g}^{-1}$ soil $24 \mathrm{~h}^{-1}$ as described by Cassida et al., (1964)

\section{Results and Discussion}

Soil urease activity $\left(\mu \mathrm{g} \mathrm{NH}_{4}^{+}\right.$released $\mathrm{g}^{-1}$ soil $2 \mathbf{h}^{-1}$ )

Urease is unique among soil enzymes and greatly affects the fate and performance of important fertilizer like urea. Soil urease catalyzes the hydrolysis of urea to carbondioxide and $\mathrm{NH}_{4}{ }^{+}-\mathrm{N}$, a form which is mostly used by plants.

A close perusal of data indicated significant differences between crop growth stages and treatments. Significantly highest urease activity was found in treatment $\mathrm{T}_{8}(100 \% \mathrm{RDF}$ $+\mathrm{SV}_{4} @ 6 \mathrm{t} \mathrm{ha}^{-1}$ ) with a value of 43.27, 55.30 and $34.15 \mu \mathrm{g}$ of $\mathrm{NH}_{4}{ }^{+}-\mathrm{N}$ released $\mathrm{g}^{-1}$ soil $2 \mathrm{~h}^{-1}$ at vegetative, tasseling and at harvesting stage of maize respectively, which was on par with $\mathrm{T}_{6}\left(100 \% \mathrm{RDF}+\mathrm{SV}_{3} @ 6 \mathrm{t} \mathrm{ha}^{-1}\right)$ and was significantly different from other treatments. The urease activity recorded at $\mathrm{T}_{13}(75 \% \mathrm{RDF}$ $+\mathrm{SV}_{4} @ 6 \mathrm{t} \mathrm{ha}^{-1}$ ) was found to be on par with 
$\mathrm{T}_{6}$ and $\mathrm{T}_{7}$ treatments and the treatments were superior to absolute control $\left(\mathrm{T}_{1}\right)$ which recorded lowest urease activity of 20.30, 25.60 and $15.21 \mu \mathrm{g}$ of $\mathrm{NH}_{4}{ }^{+}-\mathrm{N}$ released $\mathrm{g}^{-1}$ soil $2 \mathrm{~h}^{-1}$ (Table 1 and 2).

Soil dehydrogenase ( $\mu \mathrm{gTPF}$ produced $\mathrm{g}^{-1}$ soil $24 \mathbf{h}^{-1}$ )

Dehydrogenase is generally present in upper layer of soils. Dehydrogenase, as respiratory chain enzymes, plays the major role in the energy production of organisms. They oxidize organic compounds by transferring two hydrogen atoms. Dehydrogenase is essential component of the enzyme systems of microorganisms. Dehydrogenase activity can therefore be used as an indicator of biological redox systems and as a measure of microbial activity in soil, which in turn influences the nutrient availability to plants.

Table.1 Effect of vermisilt and inorganic fertilizers on urease activity $\left(\mu \mathrm{g} \mathrm{NH}{ }_{4}{ }^{+}-\mathrm{N}\right.$ released g ${ }^{-1}$ soil $2 \mathrm{~h}^{-1}$ ) in soil at different growth stages maize

\begin{tabular}{|c|c|c|c|}
\hline Treatments & Knee high stage & Tasseling stage & $\begin{array}{c}\text { Harvesting } \\
\text { stage }\end{array}$ \\
\hline $\mathbf{T}_{1}$ - Absolute Control & 20.30 & 25.60 & 15.21 \\
\hline$T_{2}-100 \%$ RDF & 25.31 & 32.95 & 20.33 \\
\hline$T_{3}-S V_{4}(10: 5) @ 6$ tha $^{-1}$ & 28.54 & 36.14 & 22.85 \\
\hline$T_{4}-100 \%$ RDF $+6 t^{-1} a^{-1}$ of $S_{2}$ & 30.86 & 41.35 & 25.90 \\
\hline$T_{5^{-}} 100 \% \mathrm{RDF}+4 \mathrm{tha}^{-1}$ of $\mathrm{SV}_{3}$ & 30.11 & 39.33 & 24.18 \\
\hline$T_{6}-100 \%$ RDF $+6 \mathrm{tha}^{-1}$ of $\mathrm{SV}_{3}$ & 41.66 & 52.18 & 32.62 \\
\hline$T_{7-100 \%} \mathrm{RDF}+4 \mathrm{tha}^{-1}$ of $\mathrm{SV}_{4}$ & 35.23 & 48.96 & 29.50 \\
\hline$T_{8}-100 \%$ RDF + $6 \mathrm{tha}^{-1}$ of $\mathrm{SV}_{4}$ & 43.27 & 55.30 & 34.15 \\
\hline$T_{9}-75 \%$ RDF $+6 t^{-1}$ of $S_{2}$ & 27.54 & 37.59 & 22.19 \\
\hline$T_{10}-75 \%$ RDF $+4 t^{h a-1}$ of $S_{3}$ & 26.28 & 35.12 & 21.14 \\
\hline$T_{11}-75 \% R D F+6 h^{-1}$ of $S_{3}$ & 32.51 & 45.28 & 28.36 \\
\hline$T_{12-}-75 \% R D F+4 t^{-1}$ of $S_{4}$ & 31.10 & 43.57 & 27.15 \\
\hline$T_{13-} 75 \% R D F+6 t^{-1}$ of $S_{4}$ & 38.39 & 50.63 & 30.29 \\
\hline $\operatorname{SEm}( \pm)$ & 1.17 & 1.32 & 0.90 \\
\hline $\mathrm{CD}(\mathrm{p}=\mathbf{0 . 0 5})$ & 3.43 & 3.84 & 2.62 \\
\hline
\end{tabular}


Table.2 Effect of vermisilt and inorganic fertilizers on dehydrogenase activity ( $\mu \mathrm{g}$ TPF produced $\mathrm{g}^{-1}$ soil $24 \mathrm{~h}^{-1}$ ) in soil at different growth stages of maize

\begin{tabular}{|c|c|c|c|}
\hline Treatments & Knee high stage & Tasseling stage & Harvesting stage \\
\hline $\mathbf{T}_{1}-$ Absolute Control & 312 & 553 & 211 \\
\hline $\mathrm{T}_{2}-100 \% \mathrm{RDF}$ & 453 & 787 & 303 \\
\hline$T_{3}-S_{4}(10: 5) @ 6 \mathrm{tha}^{-1}$ & 509 & 876 & 356 \\
\hline$T_{4}-100 \%$ RDF $+6 \mathrm{tha}^{-1}$ of $S V_{2}$ & 527 & 903 & 380 \\
\hline$T_{5}-100 \% R D F+4 t h a^{-1}$ of $S V_{3}$ & 568 & 951 & 418 \\
\hline 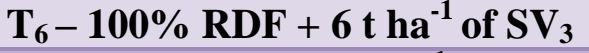 & 784 & 1201 & 624 \\
\hline $\mathrm{T}_{7}-100 \% \mathrm{RDF}+4 \mathrm{tha}^{-1}$ of $\mathrm{SV}_{4}$ & 723 & 1137 & 546 \\
\hline $\mathrm{T}_{8}-100 \% \mathrm{RDF}+6 \mathrm{tha}^{-1}$ of $\mathrm{SV}_{4}$ & 843 & 1243 & 663 \\
\hline $\mathrm{T}_{9}-75 \% \mathrm{RDF}+6 \mathrm{tha}^{-1}$ of $\mathrm{SV}_{2}$ & 475 & 854 & 336 \\
\hline$T_{10}-75 \%$ RDF $+4 \mathrm{tha}^{-1}$ of $\mathrm{SV}_{3}$ & 436 & 802 & 302 \\
\hline$T_{11}-75 \% R D F+6 t h^{-1}$ of $S_{3}$ & 651 & 1026 & 477 \\
\hline$T_{12}-75 \% R D F+4 t h^{-1}$ of $S_{4}$ & 602 & 1009 & 443 \\
\hline $\mathrm{T}_{13^{-}}-75 \% \mathrm{RDF}+6 \mathrm{tha}^{-1}$ of $\mathrm{SV}_{4}$ & 767 & 1172 & 602 \\
\hline $\operatorname{SEm}( \pm)$ & 18.8 & 28.6 & 16.0 \\
\hline $\mathrm{CD}(\mathrm{p}=0.05)$ & 55.0 & 83.4 & 46.8 \\
\hline
\end{tabular}

Significantly highest dehydrogenase activity ( $\mu \mathrm{g}$ of TPF produced $\mathrm{g}^{-1}$ soil $24 \mathrm{hr}^{-1}$ ) at vegetative (843), tasseling (1243) and harvesting stage (663) of maize was recorded with $\mathrm{T}_{8}\left(100 \% \mathrm{RDF}+\mathrm{SV}_{4} @ 6 \mathrm{tha}^{-1}\right)$ followed by $\mathrm{T}_{6}\left(100 \% \mathrm{RDF}+\mathrm{SV}_{3} @ 6 \mathrm{t} \mathrm{ha}^{-1}\right)$ @ tasseling and harvesting stage and significantly different from all other treatments. The increase in dehydrogenase activity in treatment $\mathrm{T}_{8}\left(100 \% \mathrm{RDF}+\mathrm{SV}_{4} @\right.$ $6 \mathrm{t} \mathrm{ha}^{-1}$ ) over $\mathrm{T}_{2}(100 \% \mathrm{RDF})$ was 86.09 per cent, 57.94 per cent and 118.81 per cent at vegetative, tasseling and harvest stage of the maize crop respectively. The lower dehydrogenase activity in $\mathrm{T}_{2}(100 \% \mathrm{RDF})$ as compared to other treatments with manures may be attributed to the lack of sufficient substrate i.e., OC which acts as energy source for proliferating microbial population. Similar results were reported by Reddy and Reddy (2012).

The studies on soil enzyme activities revealed that the microbial activity is maximum upto active growth stage of the maize crop. This is also clear from the dehydrogenase activity which is governed by microorganisms. Use of vermisilt provides substrate i.e., organic carbon (from both vermicompost and tanksilt) which acts as a source of energy for proliferating microorganisms, increased the microbial activity which in turn helped in releasing the nitrogen through urease activities. The sharp increase in the enzyme activities at tasseling which coincides with the active growth stage of the crop, enhanced root activity and the release of extracellular enzymes like urease into soil solutions during the active growth phase which resulted in higher rate of mineralization of nutrients in the soil. The results are in conformity with the findings of Srirama chandrasekharan et al., (1997), Srinivas et al., (2000) and Reddy and Reddy (2009).

It was concluded that application of $100 \%$ $\mathrm{RDF}+\mathrm{SV}_{4} @ 6 \mathrm{t} \mathrm{ha}^{-1}$ recorded the highest activity of urease and dehydrogenase enzyme activity in soil and were gradually increased with the age of the crop, attained highest 
activity at tasseling stage and gradually decreased till harvest.

\section{References}

Cassida, L.E., Klein, D.A and Santoro, J. 1964. Soil dehydrogenase activity. Soil Science. 98: 371-376.

Indiastat, 2017-18. http://www.indiastat.com.

Reddy, R. U and Reddy, M.S. 2012. Influence of integrated nitrogen management on dehydrogenase activity of soil in tomato-onion cropping system. Journal ofResearch ANGRAU. 40(2): 1-4.

Reddy, R.U and Reddy, M.S. 2009.Phosphatase activity in soil as influenced by Integrated Nutrient
Management in tomato-onion cropping system. Indian Journal of Agricultural Research. 43 (4): 289-293.

Srinivas, D., Raman, S and Rao, P.C. 2000. Influence of plant cover on acid and alkaline phosphatase activity in two soils of Andhra Pradesh. The Journal of Research, ANGRAU. 28(4): 40-47.

Sriramachandrasekharan, M.V., Ramanathan, $\mathrm{G}$ and Ravichandran, M. 1997. Effect of different organic manures on enzyme activities in flooded rice soil. Oryza. 34: 39-42.

Tabatabai, M.A and Bremner, J. M. 1972. Assay of urease activity in soils. Soil Biology and Biochemistry 4: 479-489.

\section{How to cite this article:}

Naveenkumar, B., G. Padmaja, T. Ram Prakash, M. Madhavi and Narender Reddy, S. 2019. Effect of Vermisilt and Inorganic Fertilizers on Urease and Dehydrogenase Enzyme Activities in soil at Different Crop Growth Stages of Maize. Int.J.Curr.Microbiol.App.Sci. 8(08): 15421546. doi: https://doi.org/10.20546/ijcmas.2019.808.181 